\begin{tabular}{|c|c|c|c|}
\hline DE & \multirow{3}{*}{$\begin{array}{l}\text { DE GRUYTER } \\
\text { OPEN }\end{array}$} & $\begin{array}{l}\text { HUNGARIAN JOURNAL OF } \\
\text { INDUSTRY AND CHEMISTRY }\end{array}$ & \multirow[t]{3}{*}{ 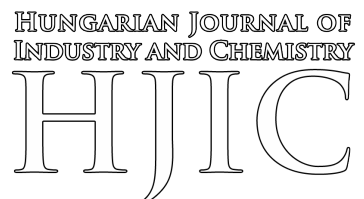 } \\
\hline & & Vol. 43(2) pp. 91-95 (2015) & \\
\hline & & $\begin{array}{l}\text { hjic.mk.uni-pannon.hu } \\
\text { DOI: } 10.1515 / \text { hjic-2015-0015 }\end{array}$ & \\
\hline
\end{tabular}

\title{
MINERAL MATTER IN NIGERIAN COALS AND TAR SAND AND THEIR IMPLICATIONS IN BINARY BLEND FORMULATION AND CO-CARBONISATION
}

\author{
Solomon A. RYemshak, ${ }^{1,2}$ Aliyu Jauro, ${ }^{1 *}$ IStifanus Y. Chindo, ${ }^{1}$ And Eno O. EkANem ${ }^{1}$ \\ 1 Department of Chemistry, Abubakar Tafawa Balewa University, P.M.B. 0248, Bauchi, \\ Bauchi State, 740003, NIGERIA \\ 2 Fuels and Energy Division, National Metallurgical Development Centre (NMDC), P.M.B. 2116 , \\ Jos, Plateau State, 930001, NIGERIA
}

\begin{abstract}
In blend simulation for metallurgical applications, the knowledge of the type and amount of mineral matter in coal and other additives, as well as their derivatives as a result of combustion is important in assessing the coke quality and blast furnace efficiency. X-ray diffraction (XRD) and X-ray fluorescence (XRF) techniques were used in assessing the mineral matter contents and oxides produced up on combustion of the following Nigerian coals: Afuze (AFZ), Garin-Maiganga (GMG), Lamza (LMZ), Shankodi-Jangwa (SKJ), and Chikila (CHK) in addition to a tar sand from Ondo (OTS). Coal samples from Afuze (AFZ) and Chikila (CHK) were found to contain quartz, hematite, and anhydride as the dominant minerals. The Garin-Maiganga coal sample (GMG) was found to contain quartz, magnetite, anhydride, and magnesite. Quartz and hematite were dominant in Lamza coal (LMZ), while Shankodi-Jangwa coal (SKJ) is associated with dolomite and quartz. The bitumen was found to contain quartz, kaolinite, and rutile. The XRF analysis revealed the presence of sixteen elemental oxides: the most abundant being silicon dioxide, ferric oxide, aluminium oxide, sulphur trioxide, calcium oxide, and titanium oxide. Amongst the coal samples, CHK, AFZ and GMG coals have low acidic/basic and basic/acidic ratios, which indicate that cokes originating from them may form the least slag with the best blast furnace efficiency.
\end{abstract}

Keywords: coke, mineral content, slag formation, fouling, flux, iron extraction

\section{Introduction}

Mineral matter and ash resulting from decomposition processes are some of the main determining factors that produce straight carbonisation and develop blend coking technology for metallurgical coke production in the iron and steel industries. The mineral matter of coal is commonly, but incorrectly termed as ash content. Coals contain mineral matter, but not ash. The latter is the solid residue, different from the mineral matter in both amount and composition that is obtained during the combustion of coal. Mineral matter has negative and positive effects on coal resource utilisation and disposal. Therefore, the characterisation of minerals in coal is essential in order to assess the beneficial and detrimental effects, which a given mineral matter may have both on the combustion process and on ultimate application. For example, even though phosphorousbearing minerals are often minor constituents of coal, they can be transferred from coal to coke and interact with iron ore, providing difficulties in steel production [1]. Consequently, coke containing a maximum value of $0.2 \%$ phosphorus is required for iron and steel production [2].

*Correspondence: ajauro@atbu.edu.ng
Compositional analysis of coal and coke ash is useful in the total coal quality description. Knowledge of the ash composition is useful in predicting the slagging and fouling characteristics of combustible materials in combustion chambers, as well as the potential utilisation of ash by-products, and environmental pollution [3]. It is well known that ash deposition on heat transfer surfaces during coal combustion is a common concern for all coal-firing boilers [4].

It is difficult to quantify the mineral matter content of a coal used in high-temperature operations (combustion and coking processes), because the minerals in coal react with organic particles. On combustion, some of the original minerals decompose and the residual substance may recombine or interact with other derivatives of the coal ash. This may lead to abrasion, corrosion, and clogging as well as fouling of the catalyst and slag formation. The ash, being inevitably a heterogeneous mixture leftover after combustion, is therefore not a true measure of the nature or amount of mineral matter originally present in the sample [5].

This paper assesses the mineral matter contents of Nigerian coals and Ondo tar sand and their implications in binary-blend formulation for coke production. 


\section{Experimental}

\subsection{Samples and Sample Preparation}

Coal samples were collected from the following coal fields: Garin-Maiganga (GMG), Chikila (CHK), Lamza (LMZ), Shankodi-Jangwa (SKJ) and Afuze (AFZ). Tar sand was obtained from Ondo (Ondo Tar Sand, OTS). The coal samples were shade dried for three days to remove the free moisture (external or primary moisture fraction). The samples were then ground, and sieved through a 250 micron $(0.25 \mathrm{~mm})$ mesh.

\subsection{Methodologies}

\subsubsection{XRD Analysis}

The powdered samples were placed into a sample holder and pressed with a piston. They were then loaded into the XRD spectrometer to determine the ore mineral contents of the samples. Copper K $\alpha$ radiation was used as the source. The spectrometer was operated at $40 \mathrm{kV}$ and $30 \mathrm{~mA}$ using continuous scan mode from 2 to 80 degrees.

\subsubsection{XRF Analysis}

Coal samples were ashed at a temperature of $825{ }^{\circ} \mathrm{C}$ for 1 hour in a muffle furnace. $5.00 \mathrm{~g}$ of the ash was mixed with a binder (cellulose flakes) in a ratio of $5: 1 \mathrm{~g} / \mathrm{g}$ and pelletised at a pressure of about 15 ton inch $^{-2}$ in a pelletising machine. The prepared samples were run on an energy-dispersed X-ray fluorescence (ED-XRF) machine by appropriating programmes for various elements, and the various oxides present detected as percentages.

\section{Results and Discussion}

\subsection{Sample Description}

Previously published data show that with the exception of Shankodi-Jangwa coal that is bituminous in rank, all other samples (AFZ, LMZ, and CHK) are of subbituminous rank [6-9].

\subsection{Mineral Matter}

Results from the XRD analysis of the major mineral matter in the coal samples and the Ondo tar sand (OTS) are shown in Figs. 1 and 2. The XRD results of the coal samples and the tar sand (OTS) revealed that quartz is dominant in all the samples, with the exception of AFZ, where hematite content is slightly higher than quartz (Fig.1). Apart from quartz, halide, and anhydride were also detected in CHK (Fig. 1); anhydride, magnetite and magnesite in GMG (Fig.1); hematite in LMZ (Fig.2); dolomite in SKJ (Fig.2); kaolinite and rutile in OTS (Fig.2). The observed minerals are commonly reported in coal samples worldwide [10].
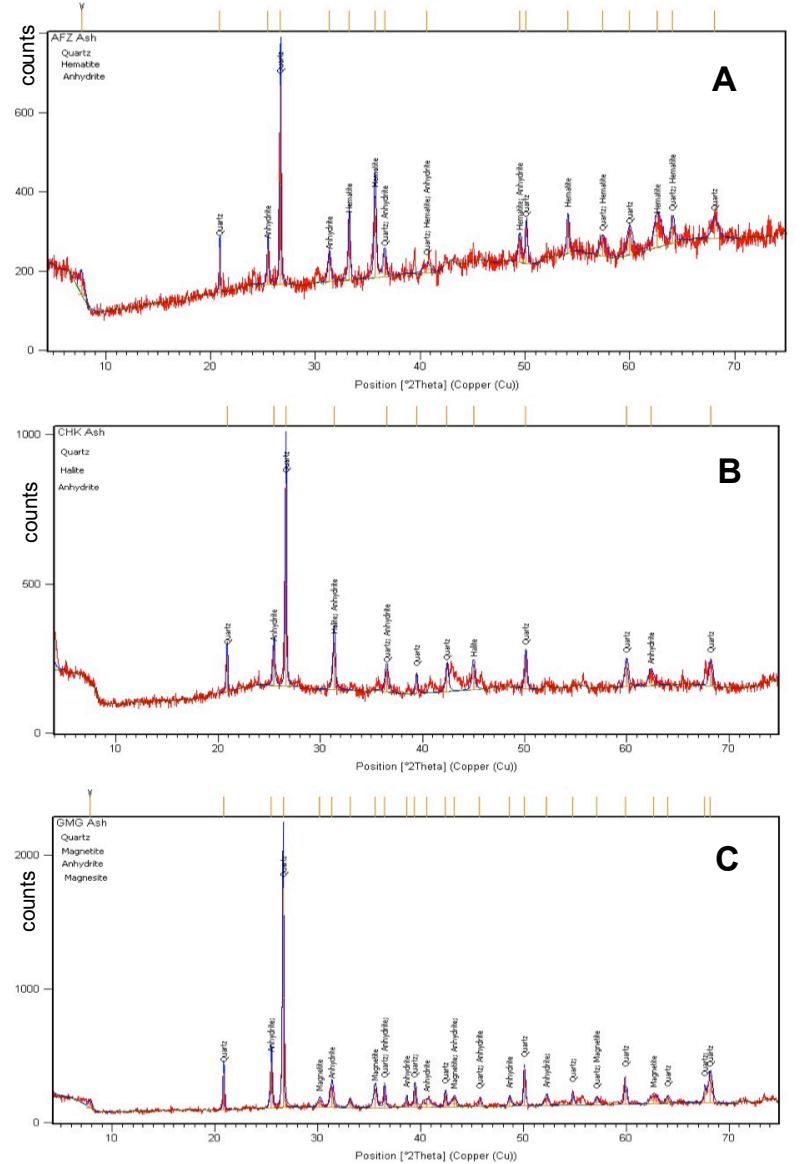

Figure 1. X-ray diffractogram of ash from A) AFZ coal (quartz $38 \%$, hematite $41 \%$, anhydrite $21 \%$ ); B) CHK coal (quartz $63 \%$, halite $13 \%$, anhydrite $25 \%$ ); C) GMG coal (quartz 56\%, magnetite $12 \%$, anhydrite $18 \%$, magnesite $14 \%$ ).

A mineral is an inorganic substance that affects both the processing and utilisation of an organic material. XRD analysis is a useful tool in the study of the effects of mineral matter on coal industrial applications like gasification, and liquefaction. Knowledge of the mineral matter can also be used to evaluate the behaviour of a particular coal in different utilisation processes, including to control the characteristics of fly ash, slag and other combustion byproducts [11]. Coal and tar sand occur in association with mineral matters, and have different mineral compositions depending on their origins. Based on the association, there are excluded minerals (minerals that are separate from the macerals) and included minerals (minerals closely associated with the organic matter) [12]. The common major minerals identified in coals are quartz, kaolinite, illite, calcite, pyrite, plagioclase, feldspar and gypsum, and occasionally dolomite, ankerite, siderite, iron-oxyhydroxides and sulphates [10]. The amount, mode of occurrence, and composition of the mineral matter in coal are factors of great practical importance in determining its marketability and economic value.

The yield and quality of the product obtained by the use of coal also depends upon the characteristics of its mineral matter. Consequently, the quality of the coke 

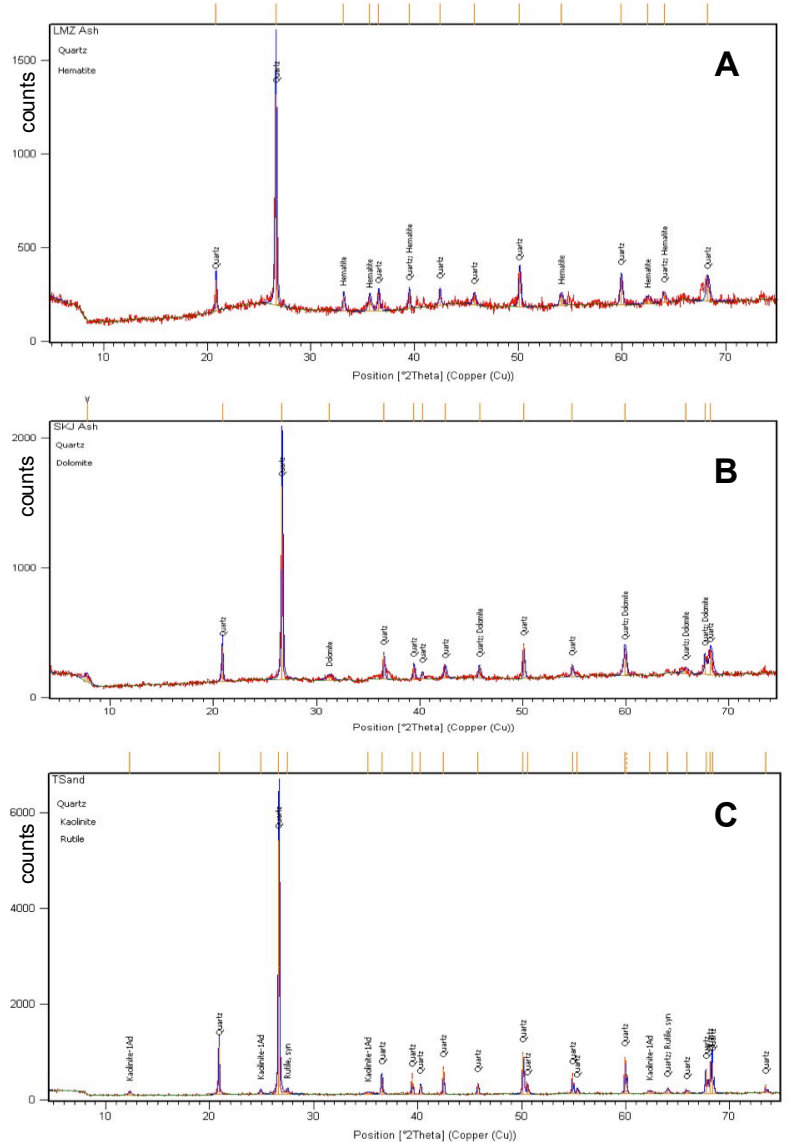

Figure 2. X-ray Diffractograms of ash from A) LMZ coal (quartz 72\%, hematite 28\%); B) SKJ coal (quartz $80 \%$, dolomite $20 \%$ ); C) OTS sample (quartz $86 \%$, kaolinite $6 \%$, and rutile $8 \%$ ).

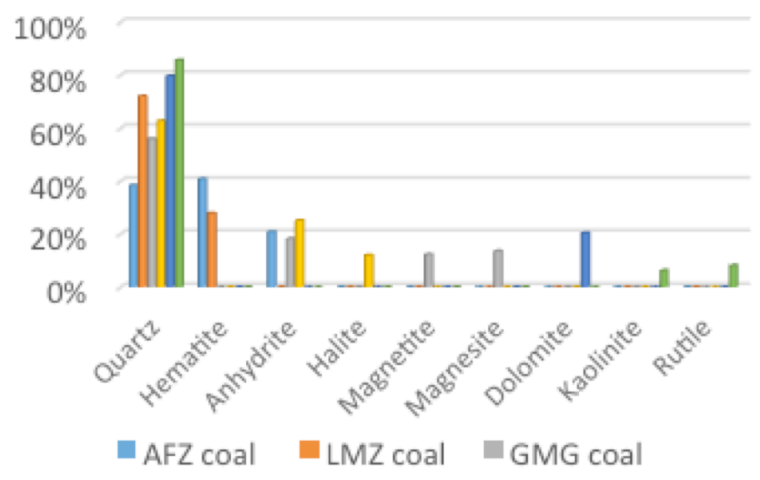

Figure 3. Mineral distribution in coal samples and the tar sand.

also depends heavily on the type and quantity of mineral matter present in the coke after carbonisation. Minerals in coals have different technological problems in metallurgy. For example, clay minerals reduce the calorific value of coal [13]. Excluded quartz and pyrite could result in the abrasion and wearing of grinding equipment [14] and pyrite could lead to slagging and fouling. However, these challenges can be mitigated by understanding coal composition, its mineralogical association and abundance.

The XRD analysis results of these samples (coals and tar sand) showed that both the coal and tar sand samples contain mineral matter impurities such as quartz and anhydride, commonly found associated with coal deposits (Fig.3). The minerals in these samples such as kaolinite, hematite, anhydrite, etc., are potential sources of raw materials of chemical industries. Some of the minerals in these coal samples, such as silica, dolomite (calcium magnesium carbonate) or calcium and aluminium are acidic, basic and neutral fluxes respectively, and are useful when combined with other impurities in the formation of slag in iron production [15].

\subsection{Mineral Matter and Ash Content During Combustion}

Some mineral matter is naturally harmful, and some can decompose to form compounds or combine with other organic components to form other derivatives during combustion. Alkali and alkali earth metals such as Li, $\mathrm{Na}, \mathrm{K}$, and $\mathrm{Ca}, \mathrm{Mg}$, respectively, at high temperatures disturb the regularity of blast furnace operation by inducing major furnace incidents like frozen hearth and burnt tuyers that cause inconsistency in iron quality. These metals also interact with other elements resulting in problems, such as clinkering, fouling, slagging and corrosion [16-17]. Alkali metals also cause lines of fracture by insertion in the carbon mass of the coke. Generally, alkaline elements were found to have a serious impact on coke production by causing decreased burden permeability and low yields [18]. The alkaline vapour sometimes acts as a glue in binding impacting ash particles together and enhancing fouling at high temperatures [19].

Ash is the inorganic residue that remains after ignition of the combustible substance, and a reduction in ash content improves the coking quality. The ash in coke is of great significance in metallurgy. According to Tivo et al. original coal ash contains various kinds of minerals, coexisting as crystal and non-crystal minerals at different temperatures [20]. Coke ash affects the operation of blast furnaces and cupolas due to both its amount and chemical composition. Industrial experience indicates that a weight percent increase of ash in the coke reduces metal production by 2 or 3 weight percent [21]. The disposal of ash is also a big problem that increases operational costs and poses some environmental challenges [22]. Ash content of less than $10 \%$ is recommended for a good coking coal [23].

\subsection{Slag Formation and Blast Furnace Efficiency}

Coal particles can behave differently particularly in terms of carbon conversion, mineral transformation, char fragmentation, and ash formation depending on the association of the organic (maceral) and inorganic (mineral) matter when fed into a gasifier or boiler [12]. This behaviour, which affects the efficiency of the boiler, can be predicted using the data from the XRF analysis of the samples. Table 1 shows the XRF analysis results of ash from the coals and tar samples. 
Table 1. Chemical composition (\% oxide content) of the coals and tar sand ashes from XRF measurements.

\begin{tabular}{|c|c|c|c|c|c|c|}
\hline Oxide & AFZ & $\mathrm{CHK}$ & GMG & LMZ & SKJ & OTS \\
\hline $\mathrm{SiO}_{2}$ & 24.61 & 29.41 & 38.60 & 46.40 & 57.36 & 70.39 \\
\hline $\mathrm{TiO}_{2}$ & 1.87 & 1.90 & 2.40 & 4.46 & 2.32 & 1.62 \\
\hline $\mathrm{Al}_{2} \mathrm{O}_{3}$ & 7.31 & 8.93 & 7.19 & 15.81 & 16.20 & 14.33 \\
\hline $\mathrm{Fe}_{2} \mathrm{O}_{3}$ & 23.97 & 18.28 & 16.26 & 22.53 & 19.30 & 5.31 \\
\hline $\mathrm{SO}_{3}$ & 13.70 & 14.70 & 11.00 & 6.20 & 1.10 & 0.09 \\
\hline $\mathrm{CaO}$ & 11.20 & 25.00 & 21.10 & 1.64 & 1.36 & 1.26 \\
\hline $\mathrm{MgO}$ & 0.35 & 0.31 & 1.96 & 0.11 & 0.20 & 0.49 \\
\hline $\mathrm{Na}_{2} \mathrm{O}$ & 0.07 & 0.15 & 0.10 & 0.05 & 0.33 & 0.30 \\
\hline $\mathrm{K}_{2} \mathrm{O}$ & 0.04 & 0.87 & 0.07 & 0.30 & 1.46 & 0.96 \\
\hline $\mathrm{MnO}$ & 0.40 & 0.04 & 0.41 & - & 0.04 & 0.06 \\
\hline $\mathrm{V}_{2} \mathrm{O}_{5}$ & 0.07 & 0.10 & 0.08 & 0.23 & 0.14 & 0.07 \\
\hline $\mathrm{Cr}_{2} \mathrm{O}_{3}$ & 0.03 & 0.03 & 0.02 & 0.04 & 0.04 & 0.03 \\
\hline $\mathrm{CuO}$ & 0.08 & 0.07 & 0.03 & 0.20 & 0.08 & 0.03 \\
\hline $\mathrm{BaO}$ & 0.30 & 0.17 & 0.77 & - & - & 0.13 \\
\hline $\mathrm{ZnO}$ & - & - & - & - & 0.04 & 0.07 \\
\hline $\mathrm{NiO}$ & - & 0.04 & 0.02 & 0.04 & 0.03 & 0.02 \\
\hline
\end{tabular}

A total of 16 elemental oxides were detected in the ashes resulting from combustion, but the most prominent ones are $\mathrm{SiO}_{2}, \mathrm{Fe}_{2} \mathrm{O}_{3}, \mathrm{Al}_{2} \mathrm{O}_{3}$, and $\mathrm{CaO}$. Even though the results of the oxides (ash composition) fall within the acceptable limit for iron production with the exception of silicon dioxide in OTS, which is above the maximum limit of $64 \%$ [2].

The ratio of acidic-to-basic (A/B) oxides $\left(\mathrm{Al}_{2} \mathrm{O}_{3}+\mathrm{SiO}_{2}\right.$ versus $\left.\mathrm{Fe}_{2} \mathrm{O}_{3}+\mathrm{CaO}+\mathrm{MgO}\right)$ characterises the ash with respect to refractoriness. The $\mathrm{A} / \mathrm{B}$ ratio indicates the ash fusion temperature and blast furnace efficiency, a high ratio leads to a high fusion temperature resulting in a high slag volume and low blast furnace efficiency [24]. The basic constituents are iron, alkali earth metals $(\mathrm{Ca}, \mathrm{Mg})$ and the alkali metals $(\mathrm{Na}, \mathrm{K})$. The acidic constituents are $\mathrm{Si}, \mathrm{Al}$, and $\mathrm{Ti}$. For instance, the coke from SKJ coal (Fig.4), which has the highest $\mathrm{A} / \mathrm{B}$ ratio is expected to exhibit the highest fusion temperature and the lowest efficiency during blast furnace operation, while the one from CHK coal would guarantee the highest efficiency of the furnace. Considering the high A/B ratio value of 12 for the OTS sample (Fig.4), a small quantity of its bitumen may be good for blend formulation with the coal samples.

The ratio of basic-to-acidic oxides (B'/A' calculated from $\mathrm{Fe}_{2} \mathrm{O}_{3}+\mathrm{CaO}+\mathrm{MgO}+\mathrm{K}_{2} \mathrm{O}+\mathrm{Na}_{2} \mathrm{O}$ content versus $\mathrm{SiO}_{2}+\mathrm{Al}_{2} \mathrm{O}_{3}+\mathrm{TiO}_{2}$ content [25]), corresponds to the slagging tendency of the coal; the higher the ratio the lower the slag formation [25]. Ash with a high B'/A' ratio, generally exhibits high ash fusion and melting temperatures. However, ash with a medium B'/A' ratio, tends to exhibit low fusion and melting temperatures, hence high slag volume. Ash with a low fusion temperature can cause problems during combustion.

The melting and viscosity behaviour has been described as a function of the composition of the coal ash in terms of acids and bases. Therefore it is expected that CHK and AFZ coals with high B'/A' ratios (Fig.5), would generate coke that may exhibit the least slag formation, closely followed by GMG coal. The highest slag volume is expected in OTS and SKJ coal.

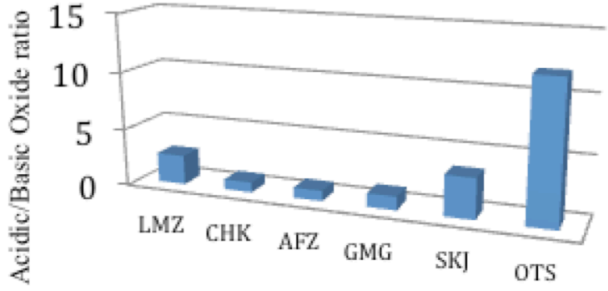

Figure 4. Blast furnace efficiencies of the coal samples.

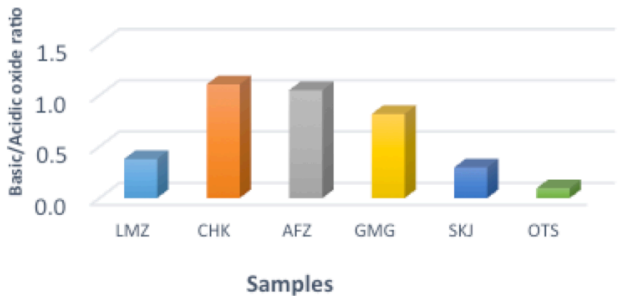

Figure 5. Slag formation tendencies of the coal and tar sand samples.

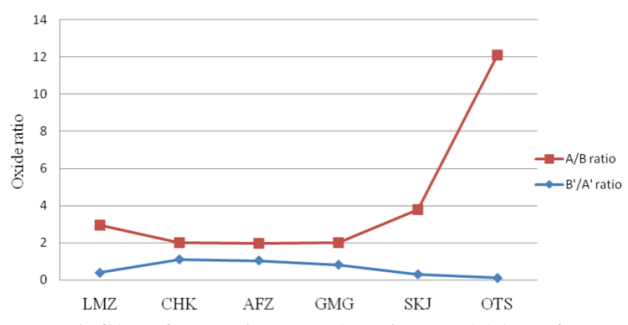

Figure 6. Slag formation tendencies and blast furnace efficiencies.

Overall, the parallel values of $\mathrm{A} / \mathrm{B}$ and $\mathrm{B}$ '/A' ratios for $\mathrm{CHK}$, AFZ, and GMG coals in Fig. 6 indicate that cokes produced from them may form the least slag and therefore the best blast furnace efficiency. Excessive ash in metallurgical coke gives rise to high slag volume and low blast furnace efficiency.

\section{Conclusion}

The relatively low ash contents of these coal samples suggest that they can safely form part of blend formulation for the production of both domestic and industrial cokes without any or significant adverse effects on fouling and slagging, and minimal corrosion and clogging tendencies. The high $\mathrm{A} / \mathrm{B}$ and low $\mathrm{B}$ '/A' ratios of the tar sand (OTS), suggest that a small amount of bitumen may be beneficial for binary blend formulation with the coals, for coke production. Based on the oxide ratios, CHK, AFZ and GMG coals may produce cokes by coking technology that may create the least slag with the best blast furnace efficiency.

\section{Acknowledgement}

We acknowledge the Department of Chemistry ATBU in Bauchi and the National Metallurgical Research and Development Centre in Jos for the use of their laboratories. The publication of this article was 
supported by Professor János Szépvölgyi (Hungarian Academy of Science, Research Centre for Natural Sciences), Professor Jude Onwudili (University of Leeds) and Dr. Biswajit Ruj (CSIR-Central Mechanical Engineering Research Institute).

\section{REFERENCES}

[1] Ward, C.R.; Corcoran, J.F.; Saxby, J.D.; Read, H.W.: Occurrence of phosphorous mineral in Australian coal seams, Int. J. Coal Geol., 1996, 30(3), 185-210 DOI: 10.1016/0166-5162(95)00055-0

[2] ASTM: Petroleum Products, Lubricants and Fossil Fuels (Annual book of ASTM standard, Easton, MD, U.S.A.) 1992

[3] Shimogori, M.; Ooyatsu, N.; Takarayama, N.; Mine, T.: Ash deposition characteristics determined in pilot plant tests burning bituminous and sub-bituminous coals, Proc. Int. Conf. Coal Sci.\& Tech. (ICCS\&T), Oviedo, Spain, 2011

[4] Basu, A.: Coal classification and analysis: coal rank, classification by heat value, Coal Industry News, 2010 http://www.coalgeology.com/coal-classificationand-analysis-coal-rank-classification-by-heat-value/8603/

[5] Ryemshak, S.A.; Jauro, A.: Proximate analysis, rheological properties and technological applications of some Nigerian coals, Int. J. Ind. Chem., 2013, 4(1), 1-7 DOI: 10.1186/2228-5547-4-7

[6] Jauro, A.: Organic geochemistry of Benue Trough coals; Biomarkers, hydrocarbon generation and coking potentials (LAP Lambert Academic Publishing, Saarbrucken, Germany) 2011

[7] Jauro, A.; Agho, M.O.; Abayeh, O.J.; Obaje, N.G.; Abubakar, M.B.: Petrographic studies and coking properties of Lamza, Chikila and Lafia-Obi Coals of Benue Trough, J. Mining \& Geol., 2008, 44(1), 37-43 DOI: 10.4314/jmg.v44i1.18882

[8] Ohimain, E.I.: Can Nigeria generate $30 \%$ of her electricity from coal?, Int. J. Energy Power Engr., 2014, 3(1), 28-37 DOI: 10.11648/j.ijepe.20140301.15

[9] Stanislav, V.V.; Vassileva, C.G.: Occurrence, abundance and origin of minerals in coals and coal ashes, J. Fuel Processing Techn., 1996, 48(2), 85106 DOI: $10.1016 /$ S0378-3820(96)01021-1

[10]Ward, C.R.: Analysis and significance of mineral matter in coal seams, Int. J. Coal Geol., 2002, 50(1), 135-168 DOI: 10.1016/S0166-5162(02)00117-9

[11]Leonard, D.C.; Bonte, L.; Dufour, A.; Ferstl, A.; Raipala, K.; Scmole, P.; Schoone, P.; Verduras, J. L.; Willmers, R.R.: Coke quality requirements of European blast furnace engineers, Proc. 3rd European Coke Making Cong., CRM-VDEh, Gent, Belgium, 1996, pp. 1-10

[12] Soundarraja, N.; Krishnamurthy, N.; Gibson, L.M.; Shadle, L.J.; Pisupati, S.V.: A study of the transformation of mineral matter in bituminous coal fractions during gasification in a drop-tube reactor, Proc. 2013 ICCS\&T, EMS Energy Institute, State College, USA, 2013, pp. 356-359
[13] Shirazi, A.R.; Bortin, O.; Eklund, L.; Lindqvist, O.: The impact of mineral matter in coal on its combustion and a new approach to the determination of the calorific value of coal, J. Fuel, 1995, 74(2), 247-251 DOI: 10.1016/0016-2361(95)92661O

[14] Spears, D.A.: Role of clay minerals in United Kingdom coal combustion, J. Appl. Clay Sci., 2000, 16(1-2), 87-95 DOI: 10.1016/S01691317(99)00048-4

[15] Dippenaar, R.: Industrial uses of slag - the use and re-use of iron and steel-making slags, Proc. 7th Int. Conf. Molten Slags Fluxes and Salts (Symposium Series S36, South African Institute of Mining \& Metallurgy), 2004, pp. 57-70

[16]Poos, A.: Future requirements for blast furnace coke making, Proc. $2^{\text {nd }}$ Int. Coke Making Congress, London, 1992, 4, 29-30

[17] James, G.S.: The chemistry and technology of coal (CRC, Boca Raton, USA) 2013

[18]Eble C.; Weisenfluh J.: Metallurgical coal resources in Eastern Kentucky. Final - PON2 127 11000027681 (Kentucky Energy and Environment Department), 2012. energy.ky.gov/fossil/Documents/ Met\%20Coal\%20Resources\%in\%20Kentucky.pdf

[19] Palanisamy, D.N.; Balakrishnan S.; Nagarajan A.: Coal desulphurisation and additive techniques to combat downstream corrosion and fouling effects: an experiment and theoretical study, Proc. Int. Conf. Coal Sci.\&Tech. (ICCS\&T), Oviedo, Spain, 2011

[20] Tivo, B.H.; Ratale, H.M.; Zhongsheng, L.; Colin, R.W.: Mineralogical characterisation of Sasol feed coals and corresponding gasification ash constituents, Energy \& Fuels, 2009, 23(6), 28672873 DOI: 10.1021/ef8010806

[21]Diez, M.A.; Avarez, R.; Barriocanal, C.: Coal for metallurgical coke production: prediction of coke quality and future requirement for coke making, Int. J. Coal Geol., 2002, 50, 289-412 DOI: 10.1016/S0166-5162(02)00123-4

[22] Jauro, A.; Chigozie, A.A.; Nasirudeen, M.B.: Determination of selected metals in coal samples from Lafia-Obi and Chikila, Sci. World J., 2008, 3(2), 79-81 www.scienceworldjournal.org/article/ view/10785

[23] Akpabio, I.O.; Chagga, M.M.; Jauro, A.: Assessment of some Nigerian coals for metallurgical application, J. Minerals Mat. Charact. Engng., 2008, 7(1), 301-306 www.scirp.org/journal/PaperDownload.aspx?paperID=20564

[24]Bo, L.; Qihui, H.; Zihao, J.; Renfu, X.; Baixing, H.: Relationship between coal ash composition and ash fusion temperatures, Fuel, 2013, 105, 293-300 DOI: 10.1016/j.fuel.2012.06.046

[25] Rod, H.: Correlating the slagging of a utility boiler with coal characteristics, (in Applications of Advanced Technology to Ash-Related Problems in Boilers, Eds.: L. Baxter; R. DeSollar.: Springer, New York, USA), 1996, pp. 237-244 DOI: $10.1007 / 978-1-4757-9223-2$ 